\title{
PENGARUH PROMOSI POLITEKNIK NEGERI TANAH LAUT BERBASIS SEMINAR MOTIVASI TERHADAP JUMLAH MAHASISWA BARU TAHUN 2016
}

\author{
MUFRIDA ZEIN ${ }^{(1)}$, ANTON KUSWOYO ${ }^{(2)}$
}

Email: kuswoyoanton@politala.ac.id

\begin{abstract}
Abstrak
Jumlah lulusan SMA/Sederajat di Kabupaten Tanah Laut mencapai lebih dari 2.500 setiap tahunnya. Namun dari jumlah tersebut hanya sebagian kecil saja yang mau melanjutkan pendidikan tinggi. Faktornya bermacam-macam yaitu karena finansial, kurangnya pengetahuan tentang perguruan tinggi, dan rendahnya motivasi untuk melanjutkan pendidikan tinggi. Sejalan dengan hal tersebut, di Kabupaten Tanah Laut telah didirikan Politeknik Negeri Tanah Laut (Politala). Kampus ini didirikan dengan tujuan agar lulusan Sekolah Menengah Atas (SMA) dan sederajat bisa melanjutkan pendidikan tinggi dengan biaya yang terjangkau dan dengan jarak yang tidak jauh dari tempat tinggal. Guna meningkatkan jumlah mahasiswa baru, maka dilakukan Promosi Politeknik Negeri Tanah Laut Berbasis Seminar Motivasi bagi siswa SMA/Sederajat kelas 3. Kegiatan Promosi Politala berisi informasi kampus Politala, jurusan, alur pendaftaran, biaya kuliah, suasan perkuliahan, dan motivasi mengenai pentingnya melanjutkan pendidikan tinggi. Hasilnya, pada tahun 2016 jumlah mahasiswa baru meningkat dibandingkan dua tahun sebelumnya. Jumlah mahasiswa baru selama tiga tahun terakhir, tahun 2014, 2015, dan 2016 secara berturut-turut adalah 139 orang, 211 orang, dan 281 orang. Hal ini menunjukkan bahwa dengan adanya Promosi Berbasis Seminar Motivasi, meningkatkan jumlah mahasiswa baru di Politala.
\end{abstract}

Kata kunci: Lulusan SMA/Sederajat, promosi, motivasi, Tanah Laut.

\section{PENDAHULUAN}

Bagi banyak orang, melanjutkan pendidikan tinggi merupakan cita-cita utama. Harapannya dengan menempuh pendidikan tinggi, akan mampu meningkatkan kualitas hidup. Tidak hanya itu, dengan pendidikan tinggi, masyarakat berharap agar memiliki pengetahuan yang luas dan budi pekerti yang luhur. Begitu besar peran pendidikan bagi kesejahteraan dan kemajuan suatu bangsa, sehingga masyarakat Indonesia selayaknya mendapatkan pendidikan yang sebaik-baiknya. 
Menurut Ki Hajar Dewantara pendidikan merupakan proses pembudayaan yakni suatu usaha memberikan nilai-nilai luhur kepada generasi baru dalam masyarakat yang tidak hanya bersifat pemeliharaan tetapi juga dengan maksud memajukan serta memperkembangkan kebudayaan menuju ke arah keluhuran hidup kemanusiaan, (Hadi, 2008).

Ki Hajar Dewantara membedakan antara sistem "Pengajaran" dan "Pendidikan". Pendidikan dan pengajaran idealnya memerdekakan manusia secara lahiriah dan batiniah selalu relevan untuk segala zaman. Pengajaran bersifat memerdekakan manusia dari aspek hidup lahiriah, yakni kemiskinan dan kebodohan). Sedangkan pendidikan lebih memerdekakan manusia dari aspek hidup batin (otonomi berpikir dan mengambil keputusan, martabat, mentalitas demokratik, (Sahmo, 2013).

Begitu pentingnya pendidikan, namun tidak semua orang dapat melanjutkan pendidikannya ke jenjang pendidikan tinggi. Di Kabupaten Tanah Laut, tiap tahunnya meluluskan lebih dari 2.500 lulusan SMA/Sederajat (disdik.tanahlautkab.go.id). Dari jumlah lulusan tersebut, masih sangat banyak yang tidak melanjutkan pendidikan tinggi. Alasan tidak melanjutkan pendidikan tinggi bermacam-macam. Umumnya karena faktor finansial, namun ada juga yang karena faktor dalam diri sendiri (motivasi kurang, kurang mendapat informasi).

Guna mengatasi hal tersebut, Pemerintah Kabupaten Tanah Laut mendirikan Politeknik Tanah Laut di Pelaihari pada tahun 2009. Pendirian Politeknik ini bertujuan agar lulusan SMA/Sederajat di Tanah Laut dapat melanjutkan pendidikan tinggi. Politeknik ini dirancang dengan biaya yang terjangkau dan menjadi solusi bagi yang tidak mau jauh kuliah di luar daerah.

Politeknik Tanah Laut terus berkembang, pada tahun 2014 statusnya dinegerikan dan mendapat akreditasi B. Nama kampus pun berganti menjadi Politeknik Negeri Tanah Laut (Politala). Hingga saat ini memiliki tiga jurusan yakni Teknik Informatika, Teknologi Industri Pertanian, dan Mesin Otomotif.

Politala merupakan jembatan untuk meraih masa depan cemerlang bagi para lulusan SMA/Sederajat. Politala menghadirkan solusi kuliah dengan biaya terjangkau, dekat dengan tempat tinggal (khususnya bagi masyarakat Kabupaten Tanah Laut), dan memiliki tenaga pengajar profesional (lulusan ITB, ITS, UGM, UB, dan kampus luar negeri). Dengan adanya keunggulan yang dimiliki Politala, dan melihat potensi lulusan yang berjumlah besar, maka perlu dilakukan sosialisasi yang berbasis pada pemberian motivasi bagi siswa SMA/Sederajat kelas 3 yang akan lulus tahun 2016. 
Berdasarkan hasil evaluasi internal, jumlah peminat yang masuk kuliah di Politala masih perlu ditingkatkan dari tahun ke tahun. Oleh sebab itu berbagai upaya dilakukan Politala agar peminatnya terus meningkat. Upaya yang dilakukan pada tahun 2016 ini adalah dengan melalukan promosi ke setiap sekolah dan memberikan motivasi tentang betapa pentingnya melanjutkan pendidikan tinggi. Pada akhir kegiatan, dilakukan Promosi Berbasis Seminar Motivasi yang dilakukan di Kampus Politala dengan mengundang seluruh siswa SMA/Sederajat kelas 3 se-Kabupaten Tanah Laut.

Guna meningkatkan jumlah mahasiswa baru di Politala, maka dilakukan upaya pemasaran (marketing) yang didalamnya adalah promosi. Promosi (promotion): merupakan salah satu faktor penentu keberhasilan program pemasaran. Menurut Stanton (1996) promosi adalah suatu kegiatan memberitahukan (information), membujuk (persuation), dan mempengaruhi (influence). Namun memasarkan perguruan tinggi tentu berbeda dengan memasarkan suatu produk perdagangan.

Hal utama yang harus dilakukan dalam promosi perguruan tinggi adalah memberi motivasi tentang masa depan. Politala merupakan jembatan untuk meraih masa depan bagi siapa saya yang berminat untuk menimba ilmu di Politala.

Motivasi berasal dari bahasa Latin movere yang berarti gerak atau dorongan untuk bergerak. Menurut Schunk, dkk. (2008:6) "Motivasi adalah suatu proses diinisiasikannya dan dipertahankannya aktivitas yang diarahkan pada pencapaian tujuan”. Motivasi dapat timbul dari luar maupun dari dalam diri calon mahasiswa. Peran seminar motivasi yang dilakukan dalam penelitian ini adalah menumbuhkan motivasi dalam diri calon mahasiswa agar mereka menyadari pentingnya pendidikan tinggi.

Rumusan masalah dalam penelitian ini adalah apakah promosi berbasis seminar motivasi yang dilakukan di Politala dapat meningkatkan jumlah mahasiswa baru tahun 2016. Sedangkan tujuan dari Promosi Berbasis Seminar Motivasi adalah memberikan informasi yang akurat sekaligus memberikan motivasi betapa pentingnya melanjutkan jenjang pendidikan tinggi untuk masa depan yang lebih baik. Harapannya, dengan adanya kegiatan ini, jumlah mahasiswa baru Politala tahun 2016 meningkat dibandingkan tahun-tahun sebelumnya.

\section{METODE PENELITIAN}

Penelitian yang dilakukan merupakan jenis penelitian verifikasi, yang bertujuan untuk membuktikan pengaruh kegiatan sosialisasi berbasis seminar motivasi terhadap 
jumlah peminat/mahasiswa baru Politala. Penelitian dilakukan di lapangan (field research) dengan cara memberikan sosialisasi kepada siswa SMA/Sederajat kelas 3 seKabupaten Tanah Laut.

Sosialisasi dilakukan oleh tim yang terdiri dari dosen dibantu staf. Masingmasing tim berjumlah 3-5 orang, bertugas melakukan sosialisasi di sekolah-sekolah. Setiap tim dibekali dengan materi sosialisasi, brosur, dan formulir pendaftaran. Sebelum melakukan sosialisasi, semua tim diberikan pembekalan agar memiliki persepsi yang sama selama melakukan sosialisasi.

Materi sosialisasi terdiri dari:

1. Materi Promosi Politala (berisi informasi kampus Politala, jurusan, alur pendaftaran, biaya kuliah, suasan perkuliahan, dll)

\section{Motivasi Pentingnya melanjutkan Pendidikan Tinggi}

Penelitian dilakukan selama 5 (lima) bulan, bulan Pebruari-Juli 2016. Melibatkan 25 SMA/SMK/MA se-Kabupaten Tanah Laut. Pada akhir kegiatan, seluruh siswa kelas 3 diundang ke Kampus Politala untuk diberikan motivasi agar sukses menghadapi Ujian Nasional dan memiliki kemauan untuk melanjutkan jenjang pendidikan tinggi.

Setelah kegiatan sosialisasi dan motivasi selesai dilaksanakan, dilakukan evaluasi terhadap jumlah mahasiswa baru yang diterima Politala. Evaluasi dilakukan dengan membandingkan jumlah mahasiswa baru selama tiga tahun terakhir, yakni tahun 2014, 2015, dan 2016. Jika ada peningkatan jumlah mahasiswa baru, berarti metode yang diterapkan telah berhasil.

\section{HASIL DAN PEMBAHASAN}

Sosialisasi berbasis motivasi dilaksanakan di 25 sekolah SMA, SMK, dan MA se-Kabupaten Tanah Laut, baik negeri maupun swasta. Sosialisasi dilakukan di setiap sekolah-sekolah, dengan cara mendatangi sekolah oleh tim sosialisasi.

Pada bulan Maret 2016, seluruh siswa kelas 3 diundanga di Kampus Politala untuk diberikan pembekalan dan motivasi agar mereka siap menghadapi Ujian Nasional dan siap untuk melanjutkan pendidikan tinggi. Pentingnya kuliah dijelaskan oleh peneliti (Gambar 1).

Bagi siswa kelas tiga yang nantinya lulus, perjuangan belumlah selesai. Ibarat membuat sebuah produk, lulusan SMA masih berupa "barang setengah jadi" belum menjadi produk "jadi” yang siap pakai. Termasuk dalam hal cita-cita, setelah lulus 
SMA, mereka masih harus menempuh tahapan berikutnya untuk mewujudkan cita-cita mereka (Gambar 2). Tahap selanjutnya yang semestinya dilalui adalah kuliah. Meskipun kuliah bukan satu-satunya tahapan untuk mewujudkan cita-cita menjadi "seseorang", namun mayoritas anak lulusan SMA ingin kuliah. Apalagi di zaman sekarang, kuliah sudah menjadi suatu keharusan.

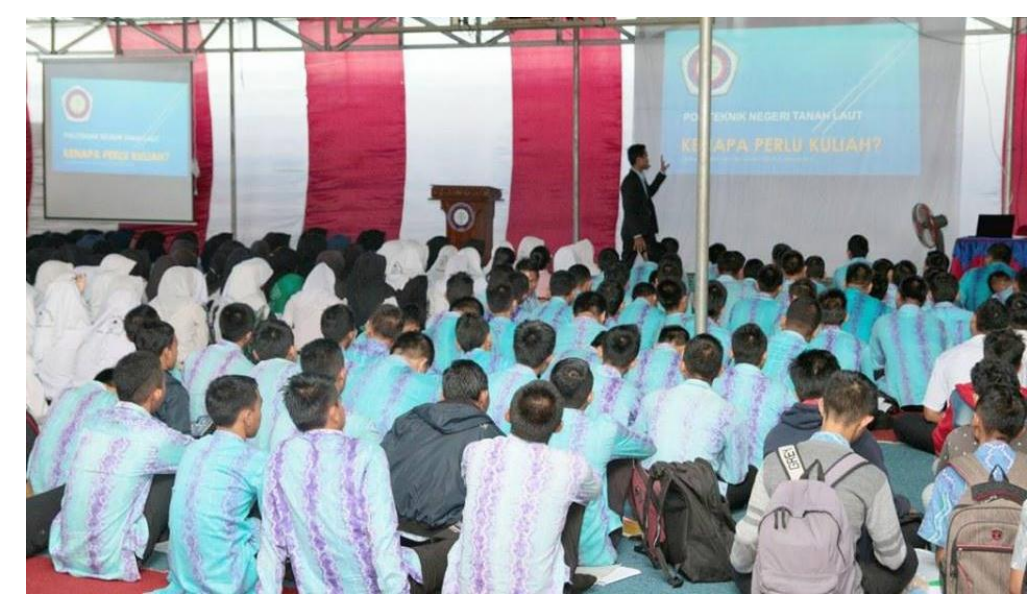

Gambar 1. Menjelaskan pentingnya kuliah

Umumnya, orang kuliah karena ingin mencapai kehidupan yang lebih baik. punya pekerjaan mapan, penghasilan lumayan, dan berkedudukan. Karena memang pendidikan itu untuk kesejahteraan masyarakat. Kini pilihan kampus (perguruan tinggi) sangat beragam. Tidak hanya disesuaikan dengan minat jurusan yang diinginkan, namun juga disesuaikan dengan kemampuan finansial orangtua calon mahasiswa. Tentu ada kualitas ada harga. Kampus dengan kualitas unggul dan fasilitas lengkap tentu saja biayanya juga mahal. Meskipun ada kampus negeri yang kualitasnya bagus dengan biaya terjangkau, tetapi seleksi masuknya super ketat. Satu kursi bisa diperebutkan puluhan hingga ratusan orang dari seluruh Indonesia. 


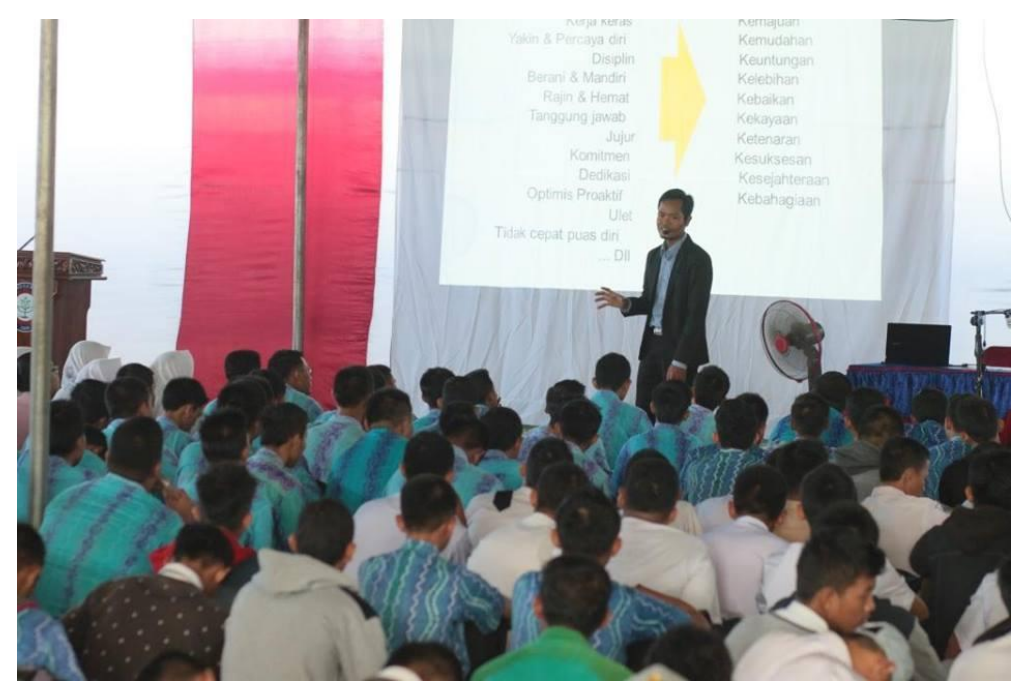

Gambar 2. Memberikan Motivasi kepada siswa SMA/Sederajat

Kampus tempat kuliah memang menentukan kualitas alumninya, namun faktor utamanya tetaplah ada pada diri mahasiswa sendiri. Tidak sedikit lulusan kampus elit tapi hingga kini masih lontang-lantung jadi pengangguran, sebaliknya ada lulusan kampus pinggiran yang justru sukses jadi pengusaha.

Idealnya, semakin tinggi pendidikan semakin besar kesejahteraan yang dapat diraih. Tetapi kenyataan di lapangan sangat berbeda dengan harapan. Ada banyak kasus justru yang berpendidikan tinggi masih pontang-panting untuk mencari sesuap nasi. Bahkan beberapa diantaranya menjadi pengangguran.

Jika melihat data pengangguran memang masih sangat memperihatinkan. Bukan saja dari segi jumlah, namun dari segi tingkat pendidikan. Diantara para pengangguran ternyata justru banyak dari lulusan perguruan tinggi. Mereka dikategorikan pengangguran terdidik.

Jika orang yang tidak berpendidikan jadi pengangguran, barangkali masih bisa dimaklumi. Namun jika orang yang berpendidikan tinggi yang jadi pengangguran, tentu ini menjadi tanda tanya besar. Untuk apa ilmunya yang telah dipelajari bertahun-tahun selama kuliah? Ataukah merekah hanya sekedar memiliki gelar belaka namun tidak memiliki kompetensi di bidangnya? Penyebab pengangguran ada dua yakni rendahnya kompetensi yang dimiliki dan terbatasnya lowongan pekerjaan yang diinginkan.

Pertama karena seseorang tidak memiliki kompetensi kerja yang dibutuhkan. Rendahnya kompetensi yang dimiliki tentu membuat orang kalah bersaing dalam memperoleh pekerjaan. Lebih-lebih di zaman sekarang ini persaingan semakin ketat. Jika ada sepuluh pencari kerja namun yang dibutuhkan hanya tiga orang, tentu yang 
diambil adalah yang paling kompeten diantara mereka. Maka ada seleksi yang sangat ketat.

Kadang kompetensi saja tidak cukup, harus ditunjang dengan kelebihan lain sebagai penunjang (softskill). Meskipun sama-sama kompeten, yang satu pandai bekerjasama dalam tim sedangkan yang lain hanya suka bekerja sendiri (egois), tentu yang dipilih adalah yang bisa bekerjasama tim. Itulah perlunya softskill mampu bekerjasama yang baik dalam tim.

Kedua karena terbatasnya lowongan pekerjaan yang diinginkan. Meskipun punya kompetensi baik, tetapi karena lowongan pekerjaan sudah terpenuhi, maka tetap saja tidak mendapatkan pekerjaan.

Nah, di sinilah perlunya strategi untuk menyikapi dua hal penyebab pengangguran tersebut. Sebagai calon mahasiswa ataupun yang sudah jadi mahasiswa, kuliahlah sungguh-sungguh. Ingat kuliah tidak bisa hanya sekedarnya saja. Asal masuk, asal kuliah, asal lulus, asal dapat gelar. Hal demikian menyebabkan diri tidak memiliki kompetensi apa-apa. Jika tidak berkompeten, hal terburuknya adalah sulit mendapatkan pekerjaan.

Maka buatlah target yang jelas selama kuliah. Target harus menguasai skill atau bidang tertentu dengan sebaik-baiknya. Penuhilah kompetensi yang diharapkan oleh tiap-tiap jurusan, agar ketika lulus memiliki kompetensi yang sesuai dengan jurusan yang diambil. Jangan lupa lengkapi diri dengan softskill (kepemimpinan, komunikasi, manajerial, kemampuan kerjasama tim, dan memiliki akhlak yang baik) agar menunjang karir kelak dikemudian hari.

Selain itu, tanamkanlah dalam pikiran (mindset) bahwa kuliah pada hakikatnya bukan untuk jadi kuli. Kuliah bukan untuk jadi pesuruh atau hanya untuk mengharapkan uluran tangan para pengguna tenaga kerja. Memang tidak ada salahnya bahwa ketika lulus kuliah lalu mencari pekerjaan. Akan tetapi persiapkanlah mental dan keterampilan yang baik, agar ketika belum mendapat pekerjaan yang diinginkan, tetap bisa survive. Sangat lebih baik lagi jika bisa menciptakan pekerjaan sendiri menjadi wirausahawan.

Kita hidup di zaman yang serba sulit. Zaman yang penuh ketidakpastian. Maka kita semua harus membentuk mental yang kuat diiringi dengan kemandirian. Tidak bisa dibayangkan bagaimana rasanya jika sudah mendapat gelar sarjana bahkan magister, namun masih menganggur. Tentu akan menjadi beban mental yang sangat berat bagi yang bersangkutan. 
Hal tersebut tidak akan terjadi jika mereka memiliki kemandirian yang dibentuk sejak masih kuliah. Agar bisa mandiri, modalnya adalah mempunyai keterampilan dan kemauan.

Sangat disarankan bagi yang berniat untuk kuliah, agar selama kuliah juga melatih kemandirian dengan cara bekerja sampingan. Karena hanya dengan bekerja maka kemandirian akan terbentuk. Lebih-lebih jika mau menciptakan pekerjaan sendiri. Sehingga ketika lulus kuliah, tetap bisa meneruskan pekerjaannya, sambil mencari pekerjaan yang diinginkan.

Dampak positifnya adalah tetap berpenghasilan meskipun belum menemukan pekerjaan yang diinginkan. Sehingga tidak menjadi pengangguran terdidik. Akan jauh lebih baik jika pekerjaan yang dirintis sejak mahasiswa tumbuh dan berkembang menjadi besar. Sehingga menyerap banyak tenaga kerja baru.

Sejatinya, kuliah adalah untuk membentuk jiwa-jiwa yang mandiri. Mandiri dalam berpikir mandiri dalam bertindak, dan mandiri dalam bermasyarakat. Sehingga keberadaannya tidak memberatkan orang lain, justru dapat membantu orang-orang di sekitarnya.

Pada akhirnya, kemandirian akan mendatangkan kesejahteraan. Kemandirian juga membentuk mental pantang menyerah. Karena hanya orang-orang yang pantang menyerah yang akan menjadi mandiri dalam segala hal.

\section{Akhir Kegiatan}

Setelah dilakukan kegiatan sosialisasi dan seminar motivasi, maka dilakukan proses penerimaan mahasiswa baru melalui tiga jalur yaitu: PMDK, UMPN, dan MANDIRI. Masing-masing seleksi ada tahap interview (Gambar 3). 

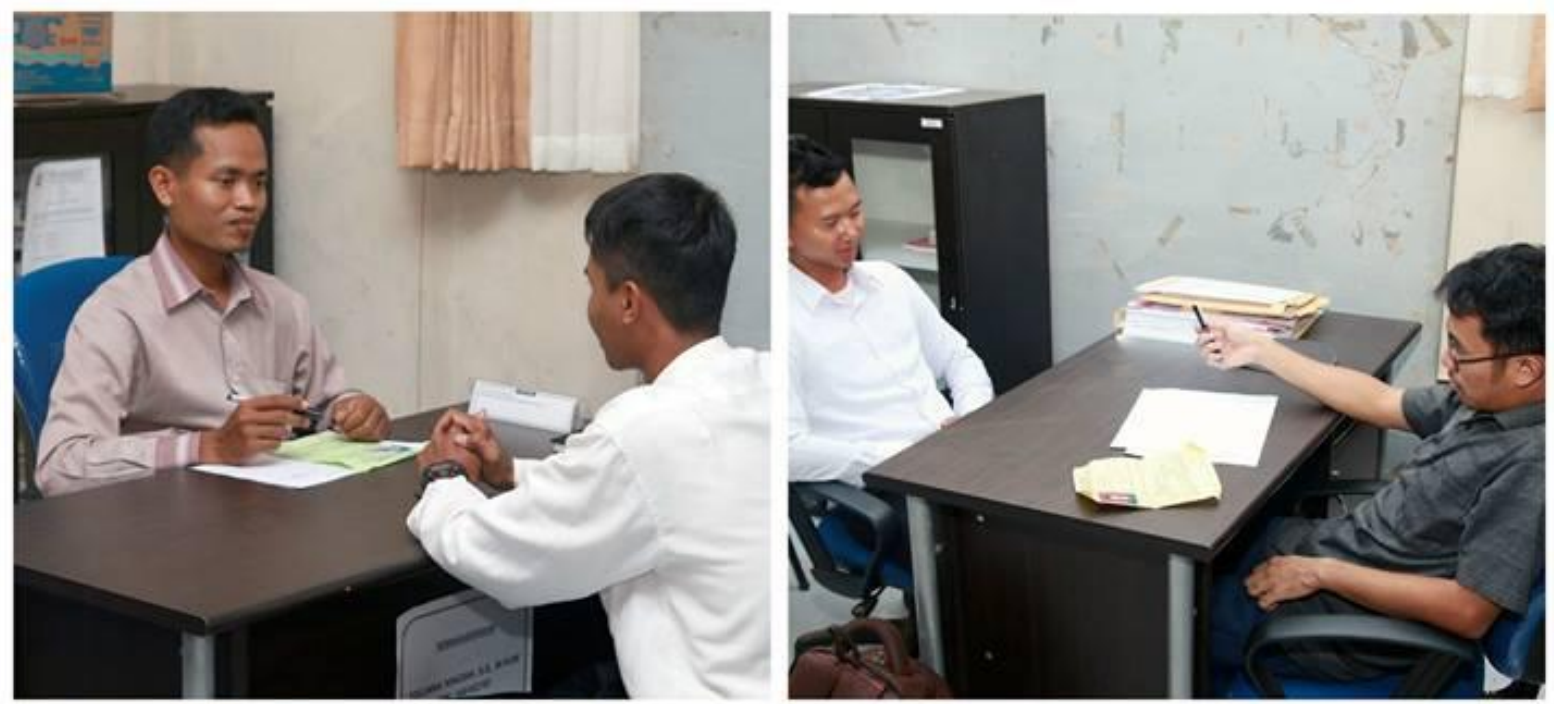

Gambar 3. Proses interview seleksi masuk Politeknik Negeri Tanah Laut

Adapun mahasiswa baru yang berhasil diterima pada tahun 2016 adalah sebanyak 281 orang. Jumlah ini meningkat dibandingkan dengan dua tahun sebelumnya (Tabel 2). Hal ini menunjukkan bahwa upaya sosialisasi dan motivasi yang dilakukan berdampak pada kenaikan jumlah mahasiswa baru tahun 2016.

Tabel 2. Jumlah Mahasiswa yang Diterima Selama 3 tahun terakhir

\begin{tabular}{|c|c|c|}
\hline No. & Tahun & Jumlah Mahasiswa yang Diterima \\
\hline 1 & 2014 & 139 \\
\hline 2 & 2015 & 211 \\
\hline 3 & 2016 & 281 \\
\hline
\end{tabular}

Sumber: Akademik Politala, 2016

\section{KESIMPULAN}

Promosi Politeknik Negeri Tanah Laut Berbasis Seminar Motivasi yang baru diterapkan pada tahun 2016 berdampak pada kenaikan jumlah peminat dan jumlah mahasiswa baru yang diterima Politeknik Negeri Tanah Laut. Jumlah mahasiswa baru selama tiga tahun terakhir, tahun 2014, 2015, dan 2016 secara berturut-turut adalah 139 orang, 211 orang, dan 281 orang. Hal ini menunjukkan bahwa dengan adanya promosi berbasis seminar motivasi, meningkatkan jumlah mahasiswa baru di Politeknik Negeri Tanah Laut. 


\section{UCAPAN TERIMA KASIH}

Ucapan terima kasih kami sampaikan kepada pimpinan Politeknik Negeri Tanah Laut yang telah mendanai penelitian ini.

\section{DAFTAR PUSTAKA}

Hadi, A.S. 2008. Pendidikan Suatu Pengantar. Surakarta: UNS Press

http://www.antarakalsel.com/berita/26123/12-siswa-tanah-laut-gagal-ikuti-un

Dakses tanggal: 13 Nopember 2016

http://www.antarakalsel.com/berita/35177/2939-siswa-ikuti-un

Dakses tanggal: 13 Nopember 2016

http://www.disdik.tanahlautkab.go.id

Dakses tanggal: 16 Nopember 2016

Sahmo, B. 2013. Visi Pendidikan Ki Hajar Dewantara. Yogyakarta: Kanisius

Schunk, D.H., Pintrich, P.R., \& Meece, J.L. 2008. Motivasi Dalam Pendidikan. Edisi 3. Terjemahan Ellys Tjo. 2012. Jakarta: PT Indeks.

Stanton, W. 1996). Prinsip-prinsip Pemasaran, Jilid Kedua, Edisi Ketujuh. Jakarta: Erlangga 